\title{
ANTICANCER ACTIVITY OF NEW COPPER(II) COMPLEXES INCORPORATING A PYRIDOXAL-SEMICARBAZONE LIGAND
}

\author{
V. Jevtovic ${ }^{1, *}$, S. Ivković ${ }^{2}$, S. Kaisarević ${ }^{3}$, R. Kovačevic ${ }^{3}$ \\ ${ }^{1}$ University of Novi Sad, Faculty of Sciences, Department of Chemistry, \\ 21000 Novi Sad, Trg D. Obradovića 3, Serbia \\ ${ }^{2}$ University EDUCONS, Faculty of Environmental Protection, \\ 21202 Sremska Kamenica, Vojvode Putnika bb, Serbia \\ ${ }^{3}$ University of Novi Sad, Faculty of Science, Department of Biology and Ecology, \\ 21000 Novi Sad, Trg D. Obradovića 3, Serbia
}

\begin{abstract}
Three newly synthesized copper complexes with pyridoxal semicarbazone (PLSC), as ligand, after being subjected to biological tests, showed anticancer activity. As ligand PLSC is biologically active, the results of biological activity are as expected. Specifically, an activity was demonstrated in breast cancer cells (MCF7 and MDA MB 231) and proliferative cells (MCF7).
\end{abstract}

Keywords: $\mathrm{Cu}(\mathrm{II})$ complex, biological investigation, anticancer activity.

\section{INTRODUCTION}

Cancer is undoubtedly one of the main health concerns facing our society and one of the primary targets regarding medicinal chemistry. Even though platinum-based complexes had been in primary focus of research on chemotherapy agents [1-3], the interests in this field have shifted to non-platinumbased agents [4-11], in order to find different metal complexes with less side effects and similar, or better, cytotoxicity. Thus, a wide variety of metal complexes based on titanium, gallium, germanium, palladium, gold, cobalt, ruthenium and tin are being intensively studied as platinum replacements [4-11]. Furthermore, copper(II)-based complexes appear to be very promising candidates for anticancer therapy; an idea supported by a considerable number of research articles describing the synthesis and cytotoxic activities of numerous copper(II) complexes [12$15]$.

The choice of the coordinated ligand(s) seems to be as important as the choice of metal(s) because besides being the integral part of biologically active complexes these organic molecules (ligands) can exert a biological activity of their own [16]. Complexes incorporating 3-hydroxy-5-hydroxymethyl-2methylpyridine-4-carboxaldehyde-3-methylisotiosemicarbazone (pyridoxal-thiosemicarbazone or PLTSC) ligand have not only been in focus of anticancer research in past several years [17-22] but also an inspiration for the synthesis of a new ligand based on pyridoxal-semicarbazide i.e. 3-hydroxy-5- hydroxymethyl-2-methyl-4-pyridinecarboxaldehyde semicarbazide or PLSC. Recently, several research articles have been published reporting the synthesis and biological activity of transition metal complexes incorporating PLSC ligand [23-29], including a review article [29] and a $\mathrm{PhD}$ thesis [30]. Coordination chemistry of PLSC-based complexes proved to be very interesting as this ligand can exist in neutral, mono-and dianionic forms depending on $\mathrm{pH}$, while its most predominant tridentate coordination mode, achieved through hydrazine nitrogen, phenolic and carbonyl oxygen atoms, allows it to be an excellent chelating ligand [30]. Furthermore, this ligand, based on semicarbazone and pyridoxal moieties (forms found in vitamin B6), has an enormous potential as a biologically active reagent as it has been demonstrated that transition metal complexes incorporating semicarbazones show biological activity. In particular, with regard to biological importance, nickel(II) complexes with semicarbazone ligands show antibacterial activity [31], and copper(II) complexes containing semicarbazones have also displayed biological properties [32-34]. Additionally, several nickel(II) complexes with octadiensemicarbazones exhibit strong inhibitory activity against Staphylococcus aureus and Eschericia Coli [35]. In vitro anticancer studies of several nickel(II) complexes with naphthoquinone semicarbazone and thiosemicarbazone on MCF-7 human breast cancer cells reveal that semicarbazone derivate with nickel(II) complexes is more actively inhibiting cell proliferation than thiosemicarbazone analogues [36]. Thus, we wish to re- 
port the anticancer activity of new Copper(II) complexes incorporating a pyridoxal-semicarbazone ligand.

\section{EXPERIMENTAL SECTION}

All commercially obtained reagent-grade chemicals were used without further purification, except for the ligand, which were prepared according to the previously described procedure [37].

The compounds were evaluated for their in vitro cytotoxicity towards two human breast adenocarcinoma cell lines (MCF7 and MDA-MB-231, respectively). Cytotoxic activity was evaluated by colorimetric sulforhodamine B (SRB) assay, after exposure of cells to tested compounds for 24 and 72 hours.

The cells were grown in Dulbecco's Modified Eagle's Medium with $4.5 \%$ of glucose (DMEM, PAA Laboratories) supplemented with $10 \%$ foetal calf serum (FCS). Cells were seeded into 96-well microliter plates at the density 5,000 cells/0.1 $\mathrm{ml} /$ well, and $24 \mathrm{~h}$ after seeding, exposed in triplicate to serial dilutions $(100-0.4 \mu \mathrm{M})$ of samples dissolved in dimethyl sulfoxide (DMSO). Control and blank wells were included in each plate. After 24 and $72 \mathrm{~h}$ SRB assay was carried out. The cells were fixed in trichloroacetic acid (TCA) $(25 \mu \mathrm{l}$ of $50 \%$ $\mathrm{w} / \mathrm{v}$ TCA per well) for $1 \mathrm{~h}$ at $4^{\circ} \mathrm{C}$, washed five times with distilled water, and stained with $50 \mu 1$ of $0.4 \%$ $\mathrm{SRB}$ in $1 \%$ acetic acid for $30 \mathrm{~min}$. The cells were washed five times with $1 \%$ acetic acid and air-dried. The stain was solubilized in $10 \mathrm{mM}$ TRIS (pH 10.5), and light absorption was measured using a plate reader (ThermoLabsystems) on $492 \mathrm{~nm}$, with reference wavelength $690 \mathrm{~nm}$. Cell cytotoxicity was expressed as a percentage of corresponding control value (non-treated cells) obtained in two independent experiments. The original data was analysed by a oneway ANOVA, followed by Duncan's multiple-range post hoc test. Differences were considered significant at $\mathrm{P}<0.05$. The IC50 values, defined as a dose of compound that inhibits cell growth by $50 \%$, were calculated from concentration-response curves.

\section{RESULTS AND DISCUSSIONS}

The reaction between 3-hydroxy-5-hydroxymethyl-2-methyl-4-pyridinecarboxaldehyde semicarbazide (pyridoxal-semicarbazide or PLSC) and appropriate chloride, sulphate, nitrate or thiocyanate $\mathrm{Cu}$ (II) salts in water/alcohol mixtures resulted in the formation of new copper(II) compl exes: $\left[\mathrm{Cu}(\mathrm{PLSC}) \mathrm{Cl}_{2}\right](1),\left[\mathrm{Cu}(\mathrm{PLSC})\left(\mathrm{H}_{2} \mathrm{O}\right)\left(\mathrm{SO}_{4}\right)\right]_{2} \cdot 3 \mathrm{H}_{2} \mathrm{O}$
(2), $\left[\mathrm{Cu}_{2}(\mathrm{PLSC})_{2}(\mathrm{NCS})_{2}\right](\mathrm{NCS})_{2}$ (3). The complexes were characterized by elemental analysis, conductometric measurements and IR spectroscopy, while complexes 1, 2 and 3 were further characterized by single crystal X-ray diffraction (Fig.1) (D. Vidovic, A. Radulovic and V. Jevtovic, Synthesis, Characterisation and Structural Analysis is of New Copper(II)Complexes Incorporating a Pyridoxal-Semicarbazone ligand, Polyhedron, 2010. Doi.: 10.1016/j.poly.2010.09.022)

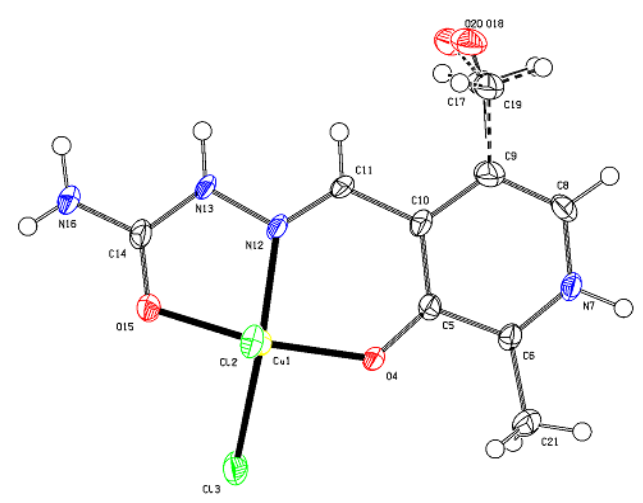

Complex 1.

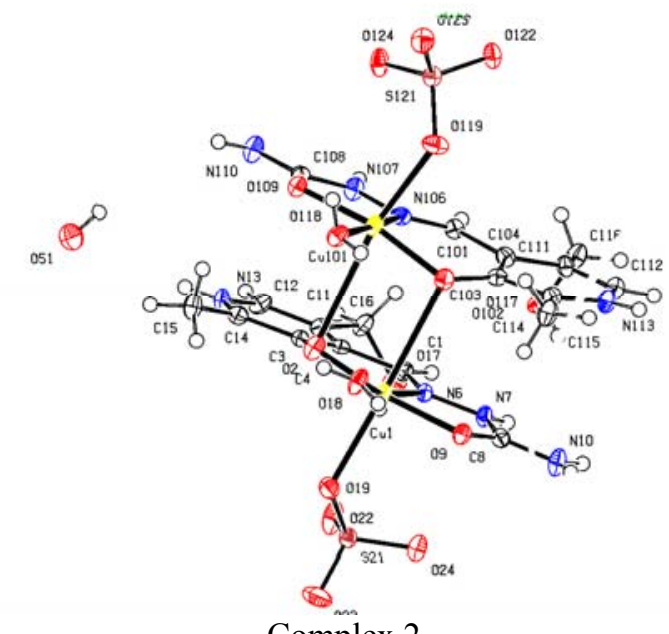

Complex 2 .

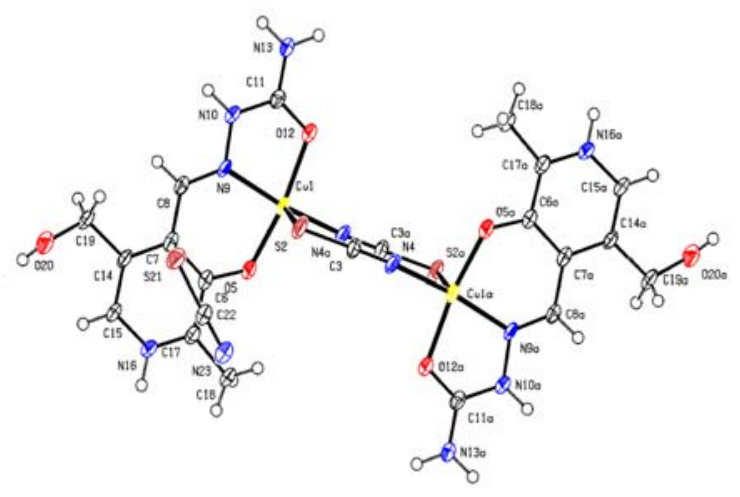

Complex 3.

Figure 1. Molecular structure of the complexes 
Their biological activities and in vitro cytotoxicity activity investigated are reported in this paper.

All the reported complexes (1 through 3 ) are crystalline solids, stable in air and at room temperature, and of characteristic green colour for $\mathrm{Cu}(\mathrm{II})$ compounds with this class of ligands [38, 39]. They are all soluble in water and in most common polar solvents.

\subsection{Cytotoxicity analysis}

Effect of tested compounds on cell proliferation was evaluated using SRB colorimetric assay, based on bonding of SRB compound with total proteins of the living cells [36]. Figure 2 shows effect of different concentrations of tested compounds on two human breast cancer cell lines (MCF7 and MDA MB 231) after 24 and $72 \mathrm{~h}$ incubation times.
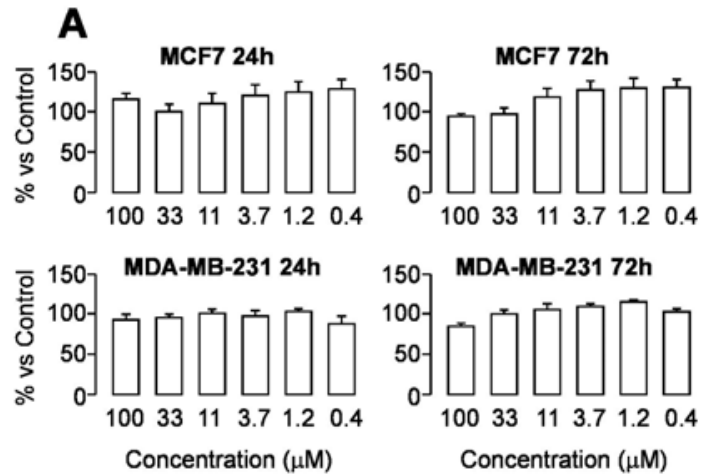

B
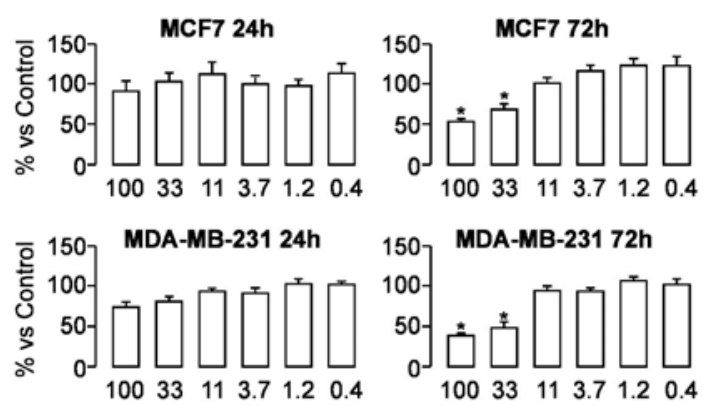

Concentration $(\mu \mathrm{M})$
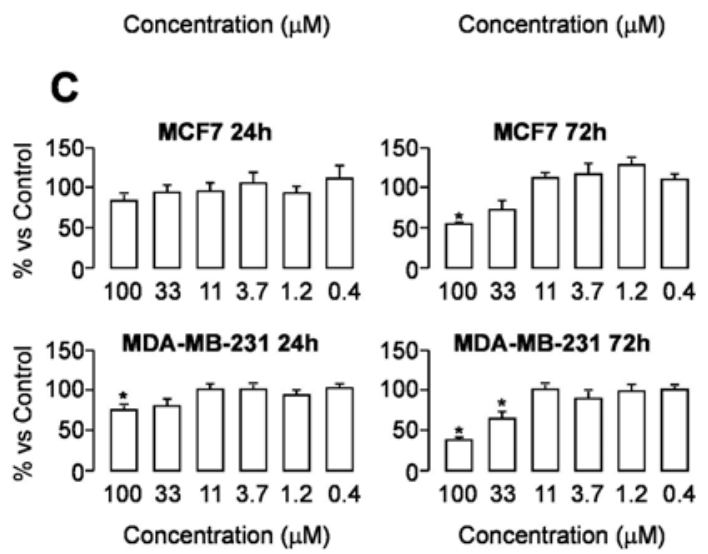

Figure 2. Effects of compounds $1(A), 2(B)$ and $\mathbf{3}(C)$ on cell proliferation of $M C F 7$ and $M D A-M B-231$ human breast cancer cell lines after 24 and 72 h of treatment.
The results suggest that compound 1 exhibit no antiproliferative effect. Compound 2 exhibits cytotoxic effects on both cell lines, but only after 72 $\mathrm{h}$ treatment by the highest tested concentrations. Similar cytotoxicity pattern was observed for compound 3. According to the report by Ferrari-Belicchi et al. [40], copper complexes with the structure very similar to the compounds tested in our study, exhibited cytotoxic effects upon TS/A murine adenocarcinoma cell line after the same exposure times, with reported IC50 values ranging from 5-8 $\mu \mathrm{M}$. In our study, the cytotoxic effect was considerably less pronounced, since calculated IC50 values for compounds 2 and 3 were in the range of $50-100 \mu \mathrm{M}$. It could be speculated that such results indicate either lower susceptibility of the human breast cancer cell lines towards the tested compounds, or their lower inhibitory action on cell proliferation.

\section{REFERENCES}

[1] B. Lippert, Cisplatin: Chemistry and Biochemistry of a Leading Anticancer Drug, Wiley Interscience 1999.

[2] A. S. Abu-Surrah, M. Kettunen, Platinum Group Antitumor Chemistry: Design and development of New Anticancer Drugs Complementary to Cisplatin, Curr. Med. Chem. 13 (2006) 1337.

[3] C. S. Allardyce, P. J. Dyson, Ruthenium in Medicine: Current Clinical Uses and Future Prospects, Platinum Met. Rev. 45 (2001) 62.

[4] I. Ott, R. Gust, Non Platinum Metal Complexes as Anti-cancer Drugs, Arch. Pharm. Chem. Life 340 (2007) 117.

[5] M. A. Jakupec, M. Galanski, V. B. Arion, C. G. Hartinger, B. K. Keppler, Antitumour metal compounds: more than theme and variations, Dalton Trans. (2008) 183.

[6] P. Yang, M. Guo, Interactions of organometallic anticancer agents with nucleotides and DNA, Coord. Chem. Rev. 185 (1999) 189.

[7] S. K. Hadjikakou, N. Hadjiliadis, Antiproliferative and anti-tumor activity of organotin compounds, Coord. Chem. Rev. 253 (2009) 235.

[8] K. Strohfeldt, M. Tacke, Bioorganometallic fulvene-derived titanocene anti-cancer drugs, Chem. Soc. Rev. 37 (2008) 1174.

[9] P. M. Abeysinghe, M. M. Harding, Antitumour bis(cyclopentadienyl) metal complexes: titanocene and molybdocene dichloride and derivatives, Dalton Trans. (2007) 3474.

[10] R. Gust, D. Posselt, K. Sommer, Development of Cobalt(3,4-diarylsalen) Complexes as Tumor Therapeutics, J. Med. Chem. 47 (2004) 5837. 
[11] C. G. Hartinger, P. J. Dyson, Bioorganometallic chemistry from teaching paradigms to medicinal applications, Chem. Soc. Rev. 38 (2009) 391.

[12] M. B. Ferrari, F. Biscegliea, G. G. Favaa, G. Pelosia, P. Tarasconi, R. Albertini, S. Pinelli, Synthesis, characterization and biological activity of two new polymeric copper(II) complexes with aketoglutaric acid thiosemicarbazone, J. Inorg. Biochem. 89 (2002) 36.

[13] M. B. Ferrari, F. Biscegliea, G. Pelosi, P. Tarasconia, R. Albertini, A. Bonati, P. Lunghi, S. Pinelli, Synthesis, characterisation, X-ray structure and biological activity of three new 5-formyluracil thiosemicarbazone complexes, J. Inorg. Biochem. 83 (2001) 169.

[14] M. R. Arguelles, M. B. Ferrari , F. Biscegli, C. Pelizzi, G. Pelosi, S. Pinelli, M. Sassi, Synthesis, characterization and biological activity of $\mathrm{Ni}$, $\mathrm{Cu}$ and $\mathrm{Zn}$ complexes of isatin hydrazones, J. Inorg. Biochem. 98 (2004) 313.

[15] M. B. Ferraria, F. Bisceglie, A. Buschini, S. Franzoni, G. Pelosi, S. Pinelli, P. Tarasconi, M. Tavone, Synthesis, structural characterization and antiproliferative and toxic bio-activities of copper(II) and nickel(II) citronellal $\mathrm{N}^{4}$ ethylmorpholine thiosemicarbazonates, J. Inorg. Biochem. 104 (2010) 199.

[16] V. Jevtovic, G. Pelosi, S. Ianelli, R. Kovacevic, S. Kaisarevic, Synthesis, Structural Studies and Biological Activity of a Dioxovanadium $(V)$ Complex with Pyridoxal Semicarbazon, Acta Chim. Slo., 57, 2 (2010) 363-369.

[17] M. Ferrari Beliccchi, G. Fava Gasparri, E. Leporati, C. Pelizzi, P. Tarasconi, G. Tosi, Thiosemicarbazones as coordinating agents. Solution chemistry and X-ray structure of pyridoxal thiosemicarbazone trihydrate and spectroscopic properties of its metal complexes, J. Chem. Soc. Dalton Trans. (1986) 2455-2461.

[18] M. Ferrari Beliccchi, G. Fava Gasparri, C. Pelizzi, P. Tarasconi, G. Tosi, Thiosemicarbazones as coordinating agents. Part 2. Synthesis, spectroscopic characterization, and X-ray structure of aquachloro(pyridoxal thiosemicarbazone)manganese(II) chloride and aqua(pyridoxal thiosemicarbazonato)-copper(II) chloride monohydrate. J. Chem. Soc. Dalton Trans. (1987) 227.

[19] M. Belicchi Ferrari, G. Fava Gasparri, P. Tarasconi, R. Albertini, S. Pinelli, R. Starcich, Synthesis, spectroscopic and structural characterization, and biological activity of aquachloro(pyridoxal thiosemicarbazone) copper(II) chloride, J. Inorg. Biochem. 53 (1994) 13.
[20] M. Belicchi Ferrari, G. Fava Gasparri, G. Pelosi, G. Rodriguez-Argulles, P. Tarasconi, Cobalt(III) complexes with thiosemicarbazones as co-ordinating agents. Spontaneous resolution by crystallization and absolute configuration, J. Chem. Soc. Dalton Trans. (1995) 3035.

[21] M. Belicchi Ferrari, G. Fava Gasparri, G. Pelizzi, G. Pelosi, P. Tarasconi, Synthetic, spectroscopic and X-ray crystallographic studies on copper(II) complexes with pyruvic acid and pyridoxal thiosemicarbazones, Inorg. Chim. Acta, (1998) 297.

[22] J. S. Casas, M. C. Rodrigues-Arguleles, U. Russo, A. Sanchez, J. Sordo, A. Vazques- Lopez, S. Pinelli, P. Lunghi, A. Bonati, R. Albertini, Diorganotin(IV) complexes of pyridoxal thiosemicarbazone: Synthesis, spectroscopic properties and biological activity, J. Inorg. Biochem. 69 (1998) 283.

[23] D. Poleti, Lj. Karanovic, V.Leovac, V. Jevtovic, Dibromo (pyridoxal semicarbazone$\left.\kappa^{3} N^{l}, O^{3}, O^{3}\right)$ copper(II), Acta Cryst. C-59 (2003) $\mathrm{m} 73$.

[24] N. Knezevic, V. Leovac, V. Jevtovic, S.Grguric-Sipka,T. Sabo, Platinum(IV) complex with pyridoxal semicarbazone, Inorg. Chem. Communications. 6 (2003) 561.

[25] V. Leovac, Lj. Jovanovic, V.Divjakovic, A. Pevec, I. Leban, T. Armbruster, Transition metal complexes with thiosemicarbazide-based ligands. Part LIV. Nickel(II) complexes with pyridoxal semi(PLSC) and thiosemicarbazone (PLTSC). Crystal and molecular structure of $\left[\mathrm{Ni}(\mathrm{PLSC})\left(\mathrm{H}_{2} \mathrm{O}\right)_{3}\right]\left(\mathrm{NO}_{3}\right)_{2}$ and $[\mathrm{Ni}(\mathrm{PLTSC}-\mathrm{H}) \mathrm{py}] \mathrm{NO}_{3}$, Polyhedron 26 (2007) 49.

[26] V. Leovac, Lj. Jovanovic, V. Jevtovic, G. Pelosi, F. Bisceglie, Transition metal complexes with thiosemicarbazide-based ligand - Part LV: Synthesis and X-ray structural study of novel Ni(II) complexes with pyridoxal semicarbazone and pyridoxal thiosemicarbazone, Polyhedron 26 (2007) 2971.

[27] V. Leovac, S. Markovic, V. Divjakovic, K. Mesaros-Secenji, M. Joksovic, I. Leban, Structural and DFT Studies on Molecular Structure of $\mathrm{Ni}$ (II) Chloride Complex with Pyridoxal Semicarbazone (PLSC). Unusual Coordination Mode of PLSC, Acta Chim. Slov. 55 (2008) 850.

[28] Z. Jacimovic, V. Leovac, G. Geister, Z.Tomic, K.Secenji-Mesaros, Structural and thermal characterization of $\mathrm{Fe}$ (III) and $\mathrm{Fe}$ (II) complexes with tridentate ONO pyridoxal semicarbazone, J. Therm. Anal. and Calo. 90 (2007) 2549.

[29] V. Leovac, V. S. Jevtovic, Lj. Jovanovic, G.A.Bogdanovic, Metal complexes with Schiff-base 
ligands - pyridoxal and semicarbazide-based derivatives, J. Serb. Chem. Soc.70 (3) (2005) 393.

[30] V. S. Jevtovic, Ph. D. Thesis, Faculty of Science, University of Novi Sad, 2002.

[31] N. C. Kasuga, K. Sekino, C. Kuomo, N. Shimada, M. Ishikawa, K. Nomiya, Synthesis, structural characterization and antimicrobial activities of 4- and 6-coordinate nickel(II) complexes with three thiosemicarbazones and semicarbazone ligands, J. Inorg. Biochem. 84 (2001) 55.

[32] P. F. Lee, C. T. Yang, D. Fan, J. J. Vittal, J. D. Ranford, Synthesis, characterization and physiccochemical properties of copper(II) complexes containing salicylaldehyde semicarbazone, Polyhedron 22 (2003) 2781.

[33] J. Patole, S. Dutta, S. Padhey, E. Sinn, Tuning up superoxide dismutase activity of copper complex of salicylaldehyde semicarbazone by heterocyclic bases pyridine and $N$-methyl imidazole, Inorg. Chim. Acta 318 (2001) 207.

[34] K. H. Reddy, P. S. Reddy, P. R. Babu, Synthesis, spectral studies and nuclease activity of mixed ligand copper(II) complexes of heteroaromatic semicarbazones/thiosemicarbazones and pyridine, J. Inorg. Biochem. 77 (1999) 169.

[35] R. Sharma, S. K. Agarwal, S. Rawat, M. Nagar, Synthesis, Characterization and Antibacterial Activity of Some Transition Metal cis-3,7-dimet- hyl-2,6-octadiensemicarbazone Complexes, Trans. Met. Chem. 31 (2006) 201.

[36] Z. Afrasiabi, E. Sinn, W. Lin, Y. Ma, C. Campana, S. Padhye, Nickel (II) complexes of naphthaquinone thiosemicarbazone and semicarbazone: Synthesis, structure, spectroscopy, and biological activity, J. Inorg. Biochem. 9 (2005)1526.

[37] V. Jevtovic, Monograph, Synthesis, physical-chemical characterisation, structure and biological activity of $\mathrm{Cu}(\mathrm{II}), \mathrm{Fe}(\mathrm{III}), \mathrm{Ni}(\mathrm{II})$, and $\mathrm{V}(\mathrm{V})$ complex with pyridoxal semi-, thiosemi- and isothiosemicarbazones, LAP Academic Publishing, Germany, 2010.

[38] N. V. Gerbeleu, Koordinatsionie soedineniya perekhodnikh elpolidentatnimi ligandami na osnove tio- $i$ selenosemikarbazida, $\mathrm{PhD}$ Thesis, MGU, Moskva, 1972.

[39] V. M. Leovac, Sinteza i ispitivanje koordinacionih jedinjenja 3d-elemenata sa Smetiltiosemikarbazidom i S-metiltiosemikarbazonima, Doktorska disertacija, Prirodno-matematički fakultet, Novi Sad, 1978.

[40] M. Ferrari Belicchi, F. Bisceglie, G. Pelosi, P. Tarasconi, R. Albertini, P.P. Dall'Aglio, S. Pinelli, A. Bergamo, G. Sava, Synthesis, characterization and biological activity of copper complexes with pyridoxal thiosemicarbazone derivatives. X-ray crystal structure of three dimeric complexes, J. of Inorg. Biochem. 98 (2004) 301.

gOP

\section{АНТИКАНЦЕРОГЕНА АКТИВНОСТ НОВИХ КОМПЛЕКСА БАКРА(ІІ) СА ЛИГАНДОМ ПИРИДОКСАЛ-СЕМИКАРБАЗОНОМ}

Сажетак: Три новосинтетисана комплекса бакра са пиридоксал-семикарбазоном (PLSC), као лигандом, применом биолошких испитивања на њима, показали су антиканцерогену активност. С обзиром на то да је сам лигад PLSC биолошки активан, резултати биолошке активности и јесу били очекивани.Конкретно, показана је активност на канцерогеним ћелијама дојке (MCF7 and MDA MB 231) и пролиферативним ћелијама (MCF7).

Кључне речи: $\mathrm{Cu}(\mathrm{II})$ комплекси, биолошка испитивања, антиканцерогена активност. 